\title{
Evaluation of Ground Water Quality Index of Piedmont Plain of Jalgaon District Using Geo-Informatics Technology
}

\author{
*Nitin S. Ghope ${ }^{1}$, Kailas P. Dandge ${ }^{1}$, M. B. Chavan ${ }^{2}$, S. T. Ingle ${ }^{1}$ \\ ${ }^{1}$ School of Environmental and Earth Sciences, North Maharashtra University, Jalgaon-425001 \\ ${ }^{2}$ Principal, K. V. R. Art's, Commerce and Science, College, Boradi \\ *Corresponding Author: ghope.nitin7@gmail.com
}

\begin{abstract}
Water quality indicates suitability of water for a specific purpose. The quality of water is based on physical, chemical and biological characteristics of water. In the present study, evaluation of groundwater quality of the piedmont plain of Jalgaon district, Maharashtra has carried out for its applicability with respect to domestic purpose. The present investigation revealed that, Water Quality Index of groundwater in the study area ranges from 35.64 to 93.12 . The minimum value has been recorded 35.64 at Puri village while maximum 93.12 has been recorded at Nimgavhan village. The analysis results of WQI indicated that, $78 \%$ of ground water samples falls in good quality whereas $22 \%$ showed excellent quality the result indicates that, groundwater of the piedmont plain of Jalgaon district is fit for drinking purpose after treatment for excess dissolved salts. The physico-chemical analysis shows that $69 \%$ samples are very hard water due to presence of $\mathrm{Ca}, \mathrm{Mg}, \mathrm{Na}$, and other metallic ions. As per the spatial distribution study, the WQI increasing trends were observed from central part towards eastern as well as western part of piedmont plain area of the Jalgaon district. The higher values of WQI were observed due to presence of higher amount of Fluorides, Alkalinity, TDS, Hardness, Bicarbonates, Calcium, EC and Sulphate in the ground water of the study region.
\end{abstract}

Keywords: Groundwater, WQI, Geo-informatics, Piedmont plain and Jalgaon district.

\section{INTRODUCTION}

The applicability of water for various uses is based on the water quality. The quality of ground water is reliant on natural impacts by geological, topographical, meteorological, hydrological and biological factors in the drainage basin and varies with seasonal variances in surface runoff volumes, weather conditions and water levels. Human interference also has considerable effect on water quality. There indices hydrological variations, such as the construction of dams, draining of wetlands and diversion of flow. Most noticeable are the polluting activities, such as the discharge of domestic, industrial, urban and other wastewaters into the waterways and the application of inorganic fertilizer and pesticides on agricultural land in the drainage basin (UNEP/WHO, 1996). Numerous studies were carried out to measure the geochemical properties of groundwater (Sujatha and Reddy, 2003; Laluraj et al., 2005; Subramani et al., 2005; Ravikumar and Somashekar, 2012). The water quality can be evaluated using physico-chemical parameters, the harmful limits of those for human health being established at both international and national level (Subramani T., 2005, WHO, 2011). Water Quality Index (WQI) is the appropriate simple statistical method to estimate the quality of water for its potability. Using the water quality data is useful for preparation or alteration of existing policies for WQI (Yang and Wang, 2010; Mohemmad et al., 2011; Tyagi et al., 2013; Tiri et al., 2014). Water quality plays a vital role in encouraging agricultural production and human health. In the $21^{\text {st }}$ century, due to modernization, industrialization and growth of population, there has been a tremendous pressure on the natural water resources (Tiwari et al., 2017).

The concept of indices to represent gradations in water quality was first proposed by (Horton, 1965) then the WQI was modified by Brown and its companion (Brown et al.,1970). The Water Quality Index (WQI) is one of the most significant and effective methods for determination of water quality. The WQI identifies the gap between WQI parameters and the uncertainty in the quality criteria (Khan et al., 2003; Soroush et al., 2011; Tirkey et al., 2016).

Remote Sensing data gives a qualitative and quantitive information of huge geographical region of the Earth surface and due to its exceptional property with better precision within short time and cost. RS 


\section{International Journal of Research in Advent Technology, Vol.7, No.4, April 2019 \\ E-ISSN: 2321-9637 \\ Available online at www.ijrat.org}

and GIS have a capability for capture, storage, manipulation, analysis and retrieval of multiple layer resource information occurring both in spatial and non-spatial data (Mishra et al., 2001). The GIS technology provides suitable substitutes for proficient supervision of large and complex database Anju et al., (2015). GIS is the computerised data generation, management, analysis and modelling techniques and

\section{STUDY AREA}

The piedmont plain of Jalgaon district was selected for the present investigation which has been originating in eastern part of Khandesh region in between Satpuda mountain and Aner - Tapi river in Jalgaon district of Maharashtra. Geographically, it is located under $21^{\circ} 00^{\prime} 40^{\prime \prime}$ to $21^{\circ} 23^{\prime} 44^{\prime \prime}$ " north latitudes and $75^{\circ} 02^{\prime} 51^{\prime \prime}$ to $76^{\circ} 02^{\prime} 39^{\prime}$ ' east longitudes (Fig. - 1). According to Census of India (2011), the total geographical area of the piedmont plain has recorded 2,118 sq. $\mathrm{km}(18.00 \%)$ out of total geographical region of the district $(11,765 \mathrm{sq}$. $\mathrm{km}$.) which constitute $0.69 \%$ of the total area of the Maharashtra state. The surrounded natural boundaries have been demarked by Tapi River at eastern and southern side, western boundary has marked by Aner River and Satpuda Mountain has covered northern it is useful in the Earth sciences. The final GIS output provided drinking water quality mapping. Anbazhagan et al, (2016). In the present study, we have evaluated ground Water Quality Index based on 36 groundwater samples from Piedmont Plain of Jalgaon district of the Maharashtra. Then, displayed geo-spatial distribution of WQI using geoinformatics techniques.

part of the piedmont plain region District Gazetteers, (1965). The climate of the study area is classified as hot summer and dry throughout the year. According to meteorological view, this region has situated in tropical region, where mean annual temperature varies from $35^{\circ} \mathrm{C}$ to $45^{\circ} \mathrm{C}$. In the past decade, the average rainfall has been fallen 75 to $80 \mathrm{~cm}$ per year in the region TERI, (2014). The piedmont area consists of alluvial plain of Tapti valley. Geologically, most of the part of study region is covered by Deccan traps excluding alluvium land on northern sides of Tapi River. These trap rocks are the result of outpouring of enormous magma flows which had extend over hundreds of kilometer of western, central and southern India to appearance a major part of the Deccan plateau at the end of Mesozoic era (Patil et al, 2015).

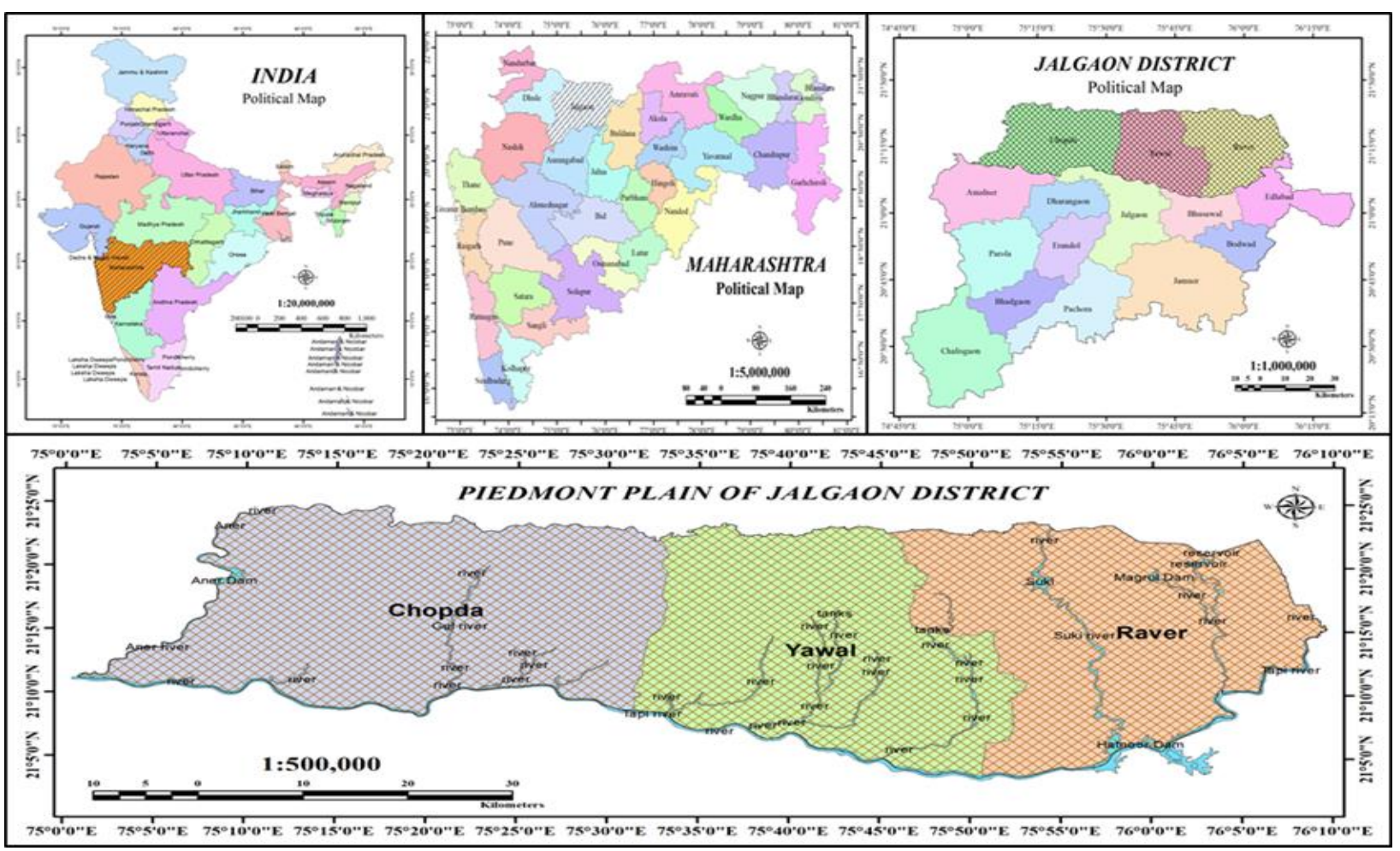

Figure: 1 - Location of Piedmont Plain of Jalgaon District. 


\section{MATERIALS AND METHODS}

In the present study, the grab groundwater samples were collected from the 36 locations by using systematic sampling techniques from piedmont plain of Jalgaon district. The samples were collected in one litre polyethylene cans which were pre-rinsed and washed in the laboratory using proportionate distilled water and hydrochloric acid, and before filling the sample it is washed thoroughly with representative sample. Global Positioning Systems (Garmin Ertex 20) was used for recording and mentioned geographical coordinates of sampling location in (Table -5 ). The standards methods were adopted for water sampling, handling, transporting, storing and laboratory analysis (APHA, 1998, Maiti, 2011). The collected samples were analysed for

\subsection{Calculation of Water Quality Index (WQI)}

The WQI was calculated using weighed arithmetic index method (Ramakrishnaiah et al, 1972, Sahu et al, 2008, Ishaku et al, 2011). In the first various water quality parameters like $\mathrm{pH}, \mathrm{EC}$, Sodium (Na) Potassium (K) Total hardness (TH) as $\mathrm{CaCO}_{3}$, Calcium $\left(\mathrm{Ca}^{2+}\right)$, Bicarbonate $\left(\mathrm{HCO}_{3}\right)$, Fluoride (Fl), Chloride $(\mathrm{Cl})$, Magnesium $(\mathrm{Mg})$, Calcium (Ca), Sulphate $\left(\mathrm{SO}_{4}\right)$, Nitrate $\left(\mathrm{NO}_{3}\right)$, Phosphate $\left(\mathrm{PO}_{4}\right)$. The Inverse Distance Weighted (IDW) approach has used for presenting spatial distribution of groundwater quality index. Groundwater quality parameters were analysed by Spearman's coefficient of correlation techniques for standardization of data in SPSS (17.0). Geo-spatial distribution of WQI trends and representation were done by applying IDW techniques for interpolation of Geo-statistical analyst tools from ArcGIS 10.2.2 software.

step, each of the 14 water quality parameters has been assigned a weight (wi) according to its relative significance in the overall quality of water for drinking purposes (Table-1).

Table: 1 - Weight and Relative weight of water quality parameters

\begin{tabular}{lccc}
\multicolumn{1}{c}{ Chemical Parameters } & Indian Standards & Weight (wi) & Relative weight (Wi) \\
\hline pH & 7 & 4 & 0.10 \\
\hline Electrical Conductivity & 500 & 3 & 0.07 \\
\hline Total hardness (TH) & 200 & 2 & 0.05 \\
\hline Total dissolved solids & 500 & 4 & 0.10 \\
\hline Magnesium & 50 & 1 & 0.02 \\
\hline Calcium & 75 & 2 & 0.05 \\
\hline Sodium & 200 & 2 & 0.05 \\
\hline Potassium & 200 & 2 & 0.05 \\
\hline Chloride & 250 & 3 & 0.07 \\
\hline Nitrate & 45 & 5 & 0.12 \\
\hline Sulphate & 200 & 4 & 0.10 \\
\hline Fluoride & 1 & 4 & 0.10 \\
\hline Alkalinity & 200 & 2 & 0.05 \\
\hline Bicarbonate & 500 & 3 & 0.07 \\
\hline & & $\sum \mathbf{w i}=\mathbf{4 1}$ &
\end{tabular}

Source: (Sahu et al, 2008, Ramakrishnaiah et al, 2009, and Ishaku et al, 2011.

The maximum weight of 5 has been given to the parameter nitrate due to its significant role in WQI. Magnesium which are given the minimum weight of 1 because it may not be harmful to human health. In the second step, the relative weight (Wi) is computed by using following formula.

$$
W i=w i \frac{w i}{\sum_{i=1}^{n} w i} \quad \text { Eq. }-(1)
$$

Where; Wi is the relative weight of parameter as per their importance in the water quality, whereas wi is the weight of each variables and $\mathrm{n}$ is the number of variables. Computed relative weight (Wi) values of each parameter are also given in (Table-1). In the third step of WQI calculation, a quality rating scale (qi) for each quality parameter is calculated by dividing its estimated concentration in 


\section{International Journal of Research in Advent Technology, Vol.7, No.4, April 2019 \\ E-ISSN: 2321-9637 \\ Available online at www.ijrat.org}

each water sample by its corresponding standard according to the guidelines of the BIS and the result multiplied by 100 .

$$
\mathrm{Qi}=(\mathbf{C i} / \mathrm{Si}) \times 100 \quad \text { Eq. }-(2)
$$

Where; qi is the quality rating, $\mathrm{Ci}$ is the concentration of each chemical parameter in each water sample in $\mathrm{mg} / \mathrm{L}$, and $\mathrm{Si}$ is the Indian drinking water standard for each chemical parameter in $\mathrm{mg} / \mathrm{L}$ according to the guidelines of the BIS 10500, 2012.

For computing the WQI, the SI is first determined for each chemical parameter by multiplying quality rating with relative weight,

\section{RESULTS AND DISCUSSIONS}

In the present investigation, $\mathrm{pH}$ was observed in the range of 8.12 to 9.15 , it was recorded highest at Korpawali village and minimum at Hingona village and $53 \%$ of samples were found beyond limits prescribed by BIS (IS 10500:2012). Higher level of $\mathrm{pH}$ in groundwater is closely correlated with the transformation of carbonate ions $\mathrm{HCO}_{3}^{-} \quad \mathrm{CO}_{3}^{-}$. similar observation was presented by the analytical chemist and hydrochemists in the various studies on water quality (Garrels et al, 1965; Drever, 1982; Krainov et al, 1992; Laptev, 1955). As per BIS pH in drinking water should be in the range finally the addition of sub-index is used to calculate WQI as per the following formula

$$
\begin{array}{cc}
\text { SIi }=\text { Wi x qi } & \text { Eq. }-(3) \\
\text { WQI }=\sum \text { SIi } & \text { Eq. }-(4)
\end{array}
$$

Where; SIi is the sub index of $\mathrm{i}^{\text {th }}$ variable; qi is the rating depends on concentration of $i^{\text {th }}$ variable and $n$ is the number of variables. The computed Water Quality Index values are classified into five types, Excellent, Good, Poor, Very Poor and Unsuitable water for drinking.

of 6.5 to 8.5 . Total alkalinity was found in the range 3.32 to $24.44 \mathrm{mg} / \mathrm{l}$. It was observed minimum at Savada village and maximum at Nimgavhan village. All locations were having alkalinity within limit prescribed by BIS. Minimum electrical conductivity $276.1 \mu \mathrm{S} / \mathrm{cm}\left(36^{\circ} \mathrm{C}\right)$ was recorded at Puri village whereas maximum $1355 \mu \mathrm{S} / \mathrm{cm}\left(36^{\circ} \mathrm{C}\right)$ at Nimgavhan village. As per Maiti, (2011) $44 \%$ of samples falls in good and $56 \%$ falls in permissible whereas none of the sample recorded as under excellent and doubtful categories (Table-2).

\begin{tabular}{|cccc|}
\hline Table: $\mathbf{2}-$ Classification of Electrical Conductivity (EC) & & \\
\hline Range & Types & No. of Samples & \% \\
\hline Below 250 & Excellent & 0 & 0 \\
\hline $\mathbf{2 5 0}-\mathbf{7 5 0}$ & Good & 16 & 44 \\
$\mathbf{7 5 0}-\mathbf{2 0 0 0}$ & Permissible & 20 & 56 \\
\hline $\mathbf{2 0 0 0}-\mathbf{3 0 0 0}$ & Doubtful & 0 & 0 \\
\hline & & $\mathbf{3 6}$ & $\mathbf{1 0 0}$ \\
\hline
\end{tabular}

Maximum hardness $616 \mathrm{mg} / \mathrm{l}$ was noted at Nirul village while minimum $140 \mathrm{mg} / \mathrm{l}$ was recorded at Puri village. As per guidelines for classification of water based on total hardness, $6 \%$ sites exabits moderate soft water while $25 \%$ was showed hard water whereas significantly $69 \%$ samples showed as very hard water and none of the sample exabit soft water (Table-3) Sawyer et al, (1967). As per WHO, 2011, Hardness is not caused by a single substance but various dissolved polyvalent metallic ions, predominantly calcium and magnesium cations, and other cations.

Table: 3 - Classification of Hardness (TH)

\begin{tabular}{cccc}
\hline Range & Types & No. of Samples & \% \\
\hline Below 75 & Soft & 0 & 0 \\
\hline $\mathbf{7 5}-\mathbf{1 5 0}$ & Moderate & 2 & 6 \\
\hline $\mathbf{1 5 0}-\mathbf{3 0 0}$ & Hard & 9 & 25 \\
\hline above 300 & Very Hard & 25 & 69 \\
\hline & & $\mathbf{3 6}$ & $\mathbf{1 0 0}$
\end{tabular}




\section{International Journal of Research in Advent Technology, Vol.7, No.4, April 2019 \\ E-ISSN: 2321-9637 \\ Available online at $w w w . i j r a t . o r g$}

Sulphate was observed in the range of 50.68 to $89.70 \mathrm{mg} / \mathrm{l}$, it was found highest at Hingona village and lowest at Wadgaon Sim village. In the study area, fluoride was significantly detected in 81 $\%$ samples which indicates fluorides contamination in the piedmont plain area of the Jalgaon district. It was detected highest $1.22 \mathrm{mg} / \mathrm{l}$ at Nimgavhan village which below permissible limit is as per BIS and minimum of $0.02 \mathrm{mg} / \mathrm{l}$ at Nimgaon village. Chlorides are salts resulting from the combination of the gas chlorine with a metal. Chlorides concentration varies from 11.91 to $281.9 \mathrm{mg} / \mathrm{l}$. It was found maximum at Savada and minimum at Vadgaon village. In the present investigation nitrate was also significantly observed at all locations. It was varied in between 0.02 to $4.91 \mathrm{mg} / \mathrm{l}$. Highest level of nitrate detected at

\section{COEFFICIENT OF CORRELATION MATRIX}

Coefficient of correlation is generally calculated to verify relationship between two variables. Correlation is measured as coefficient of correlation (r). Its arithmetical value ranges from +1.0 to -1.0 . It gives an indication of the strength of relationship between two parameters. In over all, $r>$ 0 shows positive relationship, $\mathrm{r}<0$ shows negative relationship while $r=0$ shows no relationship. If $r=$ +1.0 it shows a perfect positive correlation whereas $r$ $=-1.0$ shows a perfect negative correlation. Nearer the coefficients (r) to +1.0 and -1.0 ; greater is the strength of the association between the parameters. In the present investigation, the degree of linear relation between any two of water quality parameters, were

\section{WATER QUALITY INDEX (WQI)}

In the present investigation, the calculated WQI ranges from 35.64 to 93.12 (Table - 5). The minimum value has been recorded 35.64 at Puri
Nimgaon whereas lowest level found at Nirul village. As per BIS drinking water standards all the samples showed nitrate level below the prescribed limits. Potassium was found in the range of 1 to $4.4 \mathrm{mg} / \mathrm{l}$. Calcium and magnesium was found in the range of 20.19 to $95.88 \mathrm{mg} / \mathrm{l}$ and 14.58 to $111.78 \mathrm{mg} / \mathrm{l}$ respectively. Total Dissolved Solids (TDS) were estimated maximum $939 \mathrm{mg} / \mathrm{l}$ at Nimgavhan village whereas minimum $214 \mathrm{mg} / \mathrm{l}$ at Puri village. According to WHO, (2011); specifications TDS up to $500 \mathrm{mg} / \mathrm{l}$ is the highest desirable and up to $1500 \mathrm{mg} / \mathrm{l}$ is maximum permissible. Sodium $(\mathrm{Na})$ were found maximum $197.7 \mathrm{mg} / \mathrm{l}$ at Nimgavhan village while minimum $33.6 \mathrm{mg} / \mathrm{l}$ at Kumbharkhede village. Bicarbonate was found in the range of 3.54 to 27.57 $\mathrm{mg} / \mathrm{l}$.

measured by Spearman's correlation coefficient (r) is represented in (Table-6). TDS and EC are highly correlated $(\mathrm{r}=0.992)$ among themselves whereas Alkalinity and Bicarbonate were found highly correlated $(r=0.964)$. Similarly, Hardness to $\mathrm{Mg}$ and EC were showed highly positive correlation ( $\mathrm{r}=$ 0.944 and 0.730 respectively). Hardness of water due to carbonates of calcium and magnesium whereas permanent hardness due to sulphates and nitrates. Total dissolved solids are high due to alkalinity and sulphates (Sunita et al., 2014). Simple statistical results were obtained for water quality parameters shown in (Table-7).

while maximum has been recorded 93.12 at Nimgavhan. The calculated WQI values are classified into five types as shown in (Table - 4).

Table: 4 - Classification of WQI for potable use

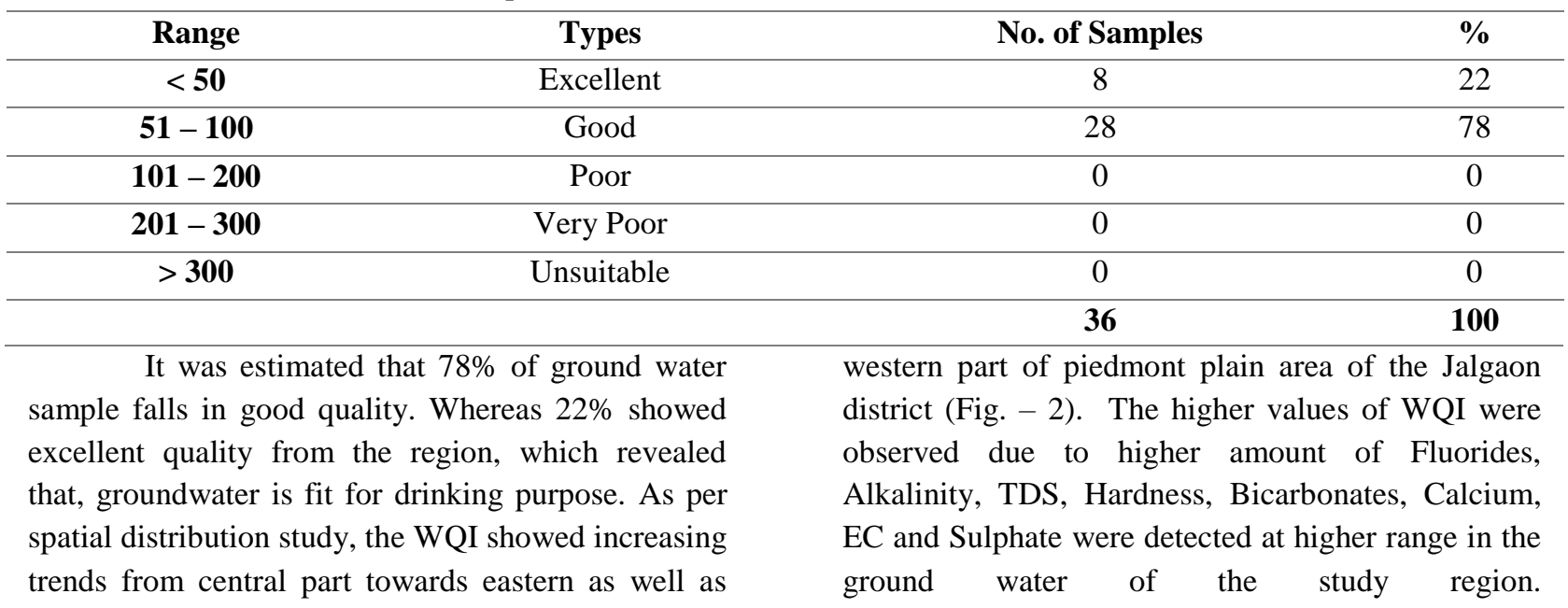


International Journal of Research in Advent Technology, Vol.7, No.4, April 2019

E-ISSN: 2321-9637

Available online at www.ijrat.org

Table: 5 - Calculated water quality index of selected sites.

\begin{tabular}{|c|c|c|c|c|c|}
\hline $\begin{array}{c}\text { Sample } \\
\text { No. }\end{array}$ & $\begin{array}{l}\text { Village } \\
\text { Name }\end{array}$ & Latitude & Longitude & Altitude & WQI \\
\hline 1 & Mohrale & 21.23 & 75.68 & 275 & 44.41 \\
\hline 2 & Ghodgaon & 21.25 & 75.11 & 186 & 55.38 \\
\hline 3 & Rozoda & 21.20 & 75.89 & 247 & 66.36 \\
\hline 4 & Duskheda & 21.08 & 75.84 & 217 & 39.73 \\
\hline 5 & Nimgaon & 21.12 & 75.73 & 208 & 63.28 \\
\hline 6 & Rukhankhede & 21.20 & 75.47 & 189 & 63.07 \\
\hline 7 & Sakali & 21.18 & 75.63 & 222 & 51.53 \\
\hline 8 & Manwel & 21.16 & 75.62 & 211 & 55.64 \\
\hline 9 & Mangrul & 21.21 & 75.39 & 193 & 66.53 \\
\hline 10 & Nhavi & 21.19 & 75.84 & 237 & 61.42 \\
\hline 11 & Nimbol & 21.19 & 76.03 & 242 & 69.95 \\
\hline 12 & Puri & 21.11 & 75.98 & 231 & 35.64 \\
\hline 13 & Pimpri & 21.31 & 76.07 & 289 & 60.13 \\
\hline 14 & Nirul & 21.28 & 76.12 & 259 & 80.60 \\
\hline 15 & Yaval & 21.17 & 75.72 & 224 & 60.70 \\
\hline 16 & Korpawali & 21.21 & 75.67 & 244 & 48.20 \\
\hline 17 & Chahardi & 21.21 & 75.22 & 181 & 55.90 \\
\hline 18 & Ganpur & 21.29 & 75.15 & 202 & 76.71 \\
\hline 19 & Wadgaon Sim & 21.17 & 75.34 & 182 & 44.37 \\
\hline 20 & Morgaon & 21.24 & 76.09 & 243 & 64.42 \\
\hline 21 & Sawada & 21.14 & 75.89 & 225 & 64.45 \\
\hline 22 & Adawad & 21.22 & 75.46 & 204 & 66.15 \\
\hline 23 & Vadgaon & 21.20 & 75.95 & 237 & 40.83 \\
\hline 24 & Kumbharkhede & 21.22 & 75.93 & 243 & 41.67 \\
\hline 25 & Dasnoor & 21.15 & 75.94 & 239 & 66.03 \\
\hline 26 & Wadode & 21.20 & 75.07 & 165 & 75.96 \\
\hline 27 & Dhamodi & 21.13 & 76.01 & 231 & 37.24 \\
\hline 28 & Warad & 21.32 & 75.29 & 256 & 65.21 \\
\hline 29 & Nimgavhan & 21.16 & 75.23 & 176 & 93.12 \\
\hline 30 & Hingona & 21.19 & 75.78 & 239 & 86.26 \\
\hline 31 & Virwade & 21.30 & 75.35 & 245 & 64.01 \\
\hline 32 & Chaugaon & 21.31 & 75.22 & 242 & 63.35 \\
\hline 33 & Padalse & 21.12 & 75.80 & 217 & 57.43 \\
\hline 34 & Kolnhavi & 21.15 & 75.55 & 201 & 56.39 \\
\hline 35 & Pal & 21.36 & 75.90 & 398 & 49.50 \\
\hline
\end{tabular}




\begin{tabular}{llllll}
\hline 36 & Dongaon & 21.18 & 75.56 & 199 & 54.94 \\
\hline
\end{tabular}

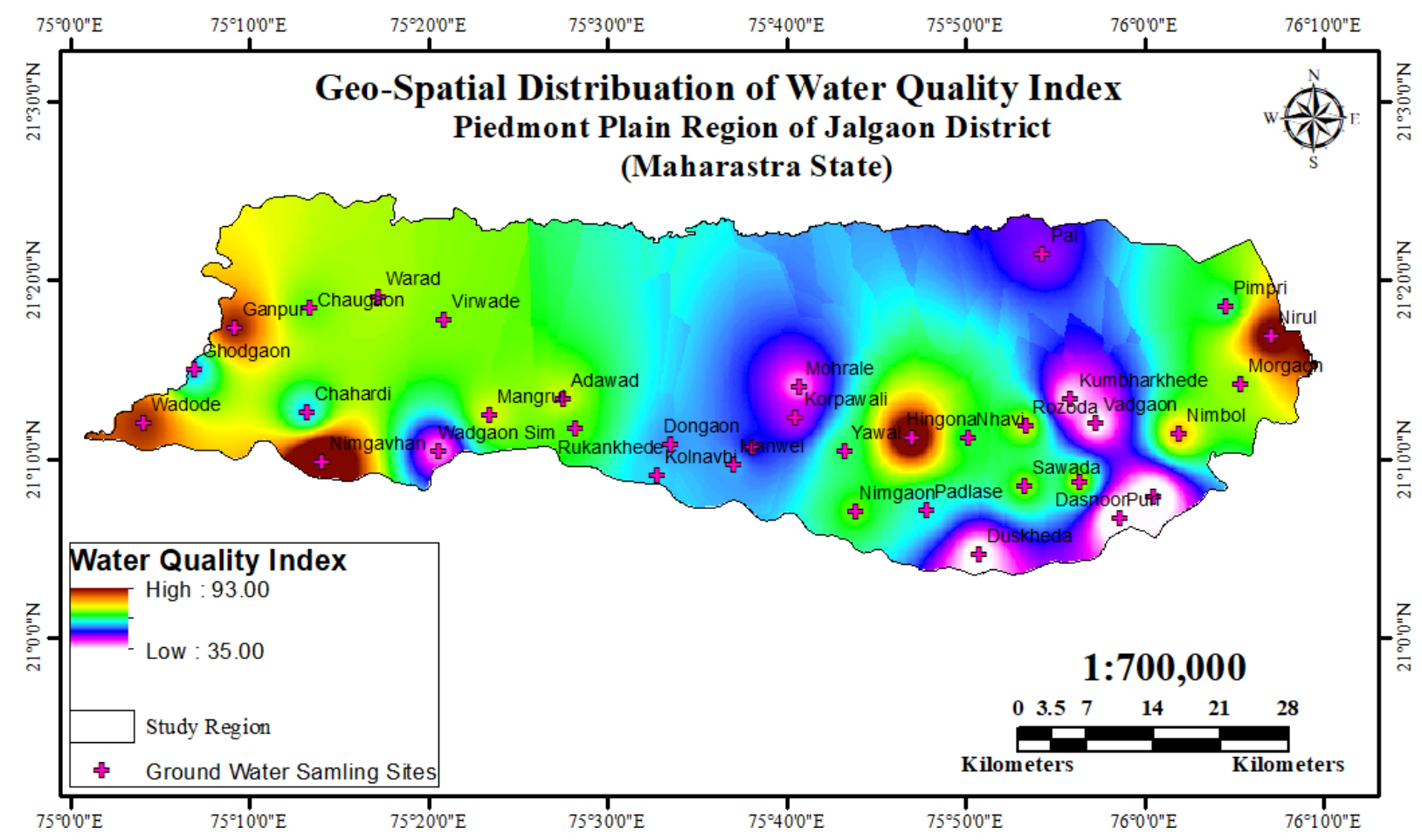

Figure: 2 - Geo-spatial distribution of Water Quality Index

\section{CONCLUSION}

The groundwater quality of the piedmont plain of Jalgaon district, Maharashtra has been evaluated for its applicability with respect to domestic purpose. The present investigation revealed that, $69 \%$ samples showed very hard water which was due to the presence of $\mathrm{Ca}, \mathrm{Mg}, \mathrm{Na}$, and other metallic ions causes the higher concentration of hardness. The water quality index ranges have found from 35.64 to 93.12 in the study region. The minimum value 35.64 has been recorded at Puri village; while maximum 93.12 has been recorded at Nimgavhan village. The analysis results of WQI indicated that, $78 \%$ of ground water sample falls in good quality whereas $22 \%$ showed excellent quality which revealed that, groundwater of the piedmont plain of Jalgaon district is fit for drinking purpose after treating it for excess dissolved salts. Results obtained by Spearman's correlation coefficient (r) cleared showed that, TDS and EC are highly correlated $(r=0.992)$ among themselves whereas Alkalinity and Bicarbonate were found highly correlated $(r=0.964)$. Similarly, Hardness to $\mathrm{Mg}$ and EC were also showed highly positive correlation $(\mathrm{r}=$ 0.944 and 0.730 respectively). In these spatial distribution study, the WQI showed increasing trends from central part towards eastern as well as western part of piedmont plain region. The higher values of WQI were observed due to presence of higher amount of Fluorides, Alkalinity, TDS, Hardness, Bicarbonates, Calcium, EC and Sulphate in the ground water of the study region. 
International Journal of Research in Advent Technology, Vol.7, No.4, April 2019

E-ISSN: 2321-9637

Available online at www.ijrat.org

Table: 6 - Spearman's Correlation Coefficient

\begin{tabular}{|c|c|c|c|c|c|c|c|c|c|c|c|c|c|c|c|}
\hline \multicolumn{2}{|c|}{$N=36$} & pH & EC & TH & TDS & Mg & $\mathbf{C a}$ & $\mathbf{N a}$ & $\mathbf{K}$ & Cl & No3 & So4 & Fl & Alkalinity & Hco3 \\
\hline \multirow[t]{2}{*}{$\mathrm{pH}$} & & 1.000 & -.136 & -.270 & -.136 & -.253 & -.254 & .137 & .290 & -.136 & -.163 & -.194 & .049 & .299 & .228 \\
\hline & Sig. (2-tailed) & 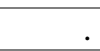 & .430 & .111 & .430 & .137 & .135 & .426 & .086 & .427 & .343 & .257 & .775 & .076 & .180 \\
\hline \multirow[t]{2}{*}{$\mathrm{EC}$} & & -.136 & 1.000 & $.730^{* * *}$ & $.992^{* *}$ & $.708^{* *}$ & $.396^{*}$ & $.728^{* *}$ & .057 & $.903^{* *}$ & .063 & $.363^{*}$ & -.202 & $.441^{* *}$ & $.426^{* *}$ \\
\hline & Sig. (2-tailed) & .430 & & .000 & .000 & .000 & .017 & .000 & .743 & .000 & .716 & .030 & .238 & .007 & .010 \\
\hline \multirow[t]{2}{*}{$\mathrm{TH}$} & & -.270 & $.730^{* * *}$ & 1.000 & $.694^{* *}$ & $.944^{* * *}$ & $.484^{* *}$ & .279 & $-.395^{*}$ & $.566^{* *}$ & .197 & .159 & -.236 & $.370^{*}$ & $.397^{*}$ \\
\hline & Sig. (2-tailed) & .111 & .000 & & .000 & .000 & .003 & .099 & .017 & .000 & .250 & .353 & .167 & .026 & .016 \\
\hline \multirow[t]{2}{*}{ TDS } & & -.136 & $.992^{* *}$ & $.694^{* * *}$ & 1.000 & $.680^{* *}$ & $.388^{*}$ & $.740^{* * *}$ & .093 & $.911^{* *}$ & .006 & $.396^{*}$ & -.194 & $.426^{* *}$ & $.410^{*}$ \\
\hline & Sig. (2-tailed) & .430 & .000 & .000 & & .000 & .019 & .000 & .590 & .000 & .974 & .017 & .257 & .009 & .013 \\
\hline \multirow[t]{2}{*}{$\mathrm{Mg}$} & & -.253 & $.708^{* *}$ & $.944^{* * *}$ & $.680^{* *}$ & 1.000 & .217 & .285 & $-.348^{*}$ & $.575^{* *}$ & .192 & .160 & -.261 & .315 & $.346^{*}$ \\
\hline & Sig. (2-tailed) & .137 & .000 & .000 & .000 & $\cdot$ & .203 & .093 & .037 & .000 & .262 & .351 & .124 & .062 & .038 \\
\hline \multirow[t]{2}{*}{$\mathrm{Ca}$} & & -.254 & $.396^{*}$ & $.484^{* *}$ & $.388^{*}$ & .217 & 1.000 & .081 & -.194 & .288 & -.050 & .224 & -.023 & .145 & .184 \\
\hline & Sig. (2-tailed) & .135 & .017 & .003 & .019 & .203 & . & .641 & .257 & .089 & .771 & .190 & .895 & .398 & .282 \\
\hline \multirow[t]{2}{*}{$\mathrm{Na}$} & & .137 & $.728^{* *}$ & .279 & $.740^{* * *}$ & .285 & .081 & 1.000 & $.415^{*}$ & $.679^{* *}$ & -.028 & .271 & -.035 & $.593^{* *}$ & $.568^{* * *}$ \\
\hline & Sig. (2-tailed) & .426 & .000 & .099 & .000 & .093 & .641 & & .012 & .000 & .869 & .109 & .842 & .000 & .000 \\
\hline \multirow[t]{2}{*}{ K } & & .290 & .057 & $-.395^{*}$ & .093 & $-.348^{*}$ & -.194 & $.415^{*}$ & 1.000 & .160 & -.259 & .163 & .154 & .104 & .058 \\
\hline & Sig. (2-tailed) & .086 & .743 & .017 & .590 & .037 & .257 & .012 & ${ }^{\circ}$ & .351 & .126 & .343 & .369 & .545 & .736 \\
\hline \multirow[t]{2}{*}{$\mathrm{Cl}$} & & -.136 & $.903^{* *}$ & $.566^{* * *}$ & $.911^{* *}$ & $.575^{* *}$ & .288 & $.679^{* *}$ & .160 & 1.000 & .055 & $.487^{* * *}$ & -.209 & .193 & .166 \\
\hline & Sig. (2-tailed) & .427 & .000 & .000 & .000 & .000 & .089 & .000 & .351 & & .750 & .003 & .221 & .261 & .333 \\
\hline \multirow[t]{2}{*}{ No3 } & & -.163 & .063 & .197 & .006 & .192 & -.050 & -.028 & -.259 & .055 & 1.000 & -.235 & .037 & .004 & .037 \\
\hline & Sig. (2-tailed) & .343 & .716 & .250 & .974 & .262 & .771 & .869 & .126 & .750 & . & .167 & .828 & .982 & .832 \\
\hline \multirow[t]{2}{*}{ So4 } & & -.194 & $.363^{*}$ & .159 & $.396^{*}$ & .160 & .224 & .271 & .163 & $.487^{* *}$ & -.235 & 1.000 & .045 & -.110 & -.149 \\
\hline & Sig. (2-tailed) & .257 & .030 & .353 & .017 & .351 & .190 & .109 & .343 & .003 & .167 & . & .794 & .524 & .387 \\
\hline \multirow[t]{2}{*}{$\mathrm{Fl}$} & & .049 & -.202 & -.236 & -.194 & -.261 & -.023 & -.035 & .154 & -.209 & .037 & .045 & 1.000 & -.078 & -.107 \\
\hline & Sig. (2-tailed) & .775 & .238 & .167 & .257 & .124 & .895 & .842 & .369 & .221 & .828 & .794 & & .653 & .535 \\
\hline \multirow[t]{2}{*}{ Alkalinity } & & .299 & $.441^{* *}$ & $.370^{*}$ & $.426^{* *}$ & .315 & .145 & $.593^{* *}$ & .104 & .193 & .004 & -.110 & -.078 & 1.000 & $.964^{* * *}$ \\
\hline & Sig. (2-tailed) & .076 & .007 & .026 & .009 & .062 & .398 & .000 & .545 & .261 & .982 & .524 & .653 & & .000 \\
\hline \multirow[t]{2}{*}{ Hco3 } & & .228 & $.426^{* *}$ & $.397^{*}$ & $.410^{*}$ & $.346^{*}$ & .184 & $.568^{* *}$ & .058 & .166 & .037 & -.149 & -.107 & $.964^{* *}$ & 1.000 \\
\hline & Sig. (2-tailed) & .180 & .010 & .016 & .013 & .038 & .282 & .000 & .736 & .333 & .832 & .387 & .535 & .000 & \\
\hline
\end{tabular}

**. Correlation is significant at the 0.01 level (2-tailed).

*. Correlation is significant at the 0.05 level (2-tailed). 
International Journal of Research in Advent Technology, Vol.7, No.4, April 2019

E-ISSN: 2321-9637

Available online at www.ijrat.org

Table: 7 - Statistical Investigation of water quality parameters.

\begin{tabular}{|c|c|c|c|c|c|c|c|c|c|c|c|c|c|c|c|}
\hline Statistical Analysis & pH & EC & TH & TDS & Mg & $\mathbf{C a}$ & $\mathbf{N a}$ & $\mathbf{K}$ & $\mathbf{C l}$ & No3 & So4 & Fl & Alkalinity & Hco3 & WQI \\
\hline Minimum & 8.12 & 276.10 & 140.00 & 214.00 & 14.58 & 20.19 & 33.60 & 1.00 & 11.91 & 0.02 & 50.68 & 0.02 & 3.32 & 3.54 & 35.64 \\
\hline Maximum & 9.15 & 1355.00 & 616.00 & 939.00 & 111.78 & 95.88 & 197.70 & 4.40 & 281.90 & 4.91 & 89.70 & 1.22 & 24.44 & 27.57 & 93.12 \\
\hline Arithmetic Mean & 8.50 & 713.28 & 359.84 & 501.96 & 60.94 & 45.86 & 79.10 & 2.38 & 93.69 & 0.98 & 68.55 & 0.49 & 13.57 & 15.31 & 59.63 \\
\hline Median & 8.51 & 767.15 & 376.00 & 520.50 & 66.10 & 43.34 & 69.55 & 2.31 & 86.27 & 0.57 & 68.11 & 0.41 & 13.24 & 15.13 & 61.06 \\
\hline Mode & \#N/A & \#N/A & 452.00 & 622.00 & 75.82 & 33.64 & \#N/A & 2.70 & 103.23 & 0.02 & 61.85 & 0.07 & 13.24 & 13.42 & \#N/A \\
\hline First Quartile & 8.38 & 477.05 & 286.00 & 366.25 & 43.25 & 33.64 & 54.33 & 1.70 & 50.13 & 0.22 & 62.02 & 0.31 & 11.38 & 13.42 & 51.02 \\
\hline Third Quartile & 8.59 & 867.73 & 445.00 & 599.50 & 78.49 & 52.57 & 100.40 & 2.80 & 116.13 & 1.10 & 74.74 & 0.66 & 15.64 & 17.93 & 66.06 \\
\hline Quartile Deviation & 0.11 & 195.34 & 79.50 & 116.63 & 17.62 & 9.46 & 23.04 & 0.55 & 33.00 & 0.44 & 6.36 & 0.17 & 2.13 & 2.26 & 7.52 \\
\hline Standard Deviation & 0.22 & 262.80 & 114.07 & 173.31 & 25.29 & 17.43 & 35.32 & 0.92 & 65.13 & 1.18 & 9.54 & 0.37 & 4.31 & 5.04 & 13.36 \\
\hline
\end{tabular}




\section{REFERENCES}

[1] Anbazhagan S., Muthumaniraja C.K., Jothibasu A., Chinnamuthu M., and Rajendran M. (2014). GIS and Spatial Evaluation of Groundwater Quality for Drinking and Irrigation Purposes in Thalaivasal Block, Southern India, International Journal of Advanced Earth Science and Engineering, Volume - 3, Issue - 1, pp. 240-253. http://scientific.cloud-

journals.com/index.php/IJAESE/article/view/Sci -238 .

[2] Anju Panwar, Sapana Bartwal, Sourabh Dangwal, Ashok Aswal, Asha Bhandari and Santosh Rawat, (2015). Water Quality Assessment of river Ganga Using remote sensing and GIS techniques; International Journal of Advanced Remote Sensing and GIS, vol. 4, Issue - 1, 1253-1261.

[3] APHA, (1998). Standard Methods for the Examination of Water and Wastewater; American Public Health Association; 20 ${ }^{\text {th }}$ edition, Washington DC, New York, USA.

[4] Ashwani Kumar Tiwari1, Abhay Kumar Singh1, Amit Kumar Singh, M. P. Singh, (2017). Hydrogeochemical analysis and evaluation of surface water quality of Pratapgarh district, Uttar Pradesh, India, Applied Water Science, 7:16091623. doi: 10.1007/s13201-015-0313-Z

[5] Bureau of Indian Standards, (2012). Indian Standards Specification for drinking Water, B. S. - 10500; Governmet of India; New Delhi.

[6] Brown, R. M., McClelland, N. I., Deininger, R. A. and Tozer, R. G., (1970). A water quality index: Do we dare? Water and Sewage Works, 117, 339-343.

[7] Census of India, (2011). District Census Handbook Jalgaon, Directorate of Census Operations Series - 28, Part - XII - A \& B, Govt. of Maharashtra, India.

[8] District Gazetteers, (1965). Jalgaon District, Directorate of Government Printing, Stationary and Publication, Bombay, Maharashtra State, Govt. of India. (Revised Edition).

[9] Drever J., (1982). The Geochemistry of Natural Water, Englewood Cliffs; Pretice-Hall, Translated under the title Geokhimiya prirodnykh vod, Moscow: Mir, 1985.

[10] Garrels R. M. and Christ C. L., (1965). Solutions, Minerals and Equilibria, New York; Harper \& Row, Translated under the title Rastvory, mineraly, ravnovesiya, Moscow: Mir, 1968.

[11] Horton, R. K., (1965). An index number system for rating water quality, Journal Water Pollution Control Federation, No. (37), pp. 300-305. http://dx.doi.org/ 10.1080/19443994.2014.972983.

[12] Ishaku J. M., Ahmed A. S. \& Abubakar M. A., (2011). Assessment of groundwater quality using chemical indices and GIS mapping in Jada area, North-eastern Nigeria, Journal of Earth Sciences and Geotechnical Engineering, Vol. -1, (1), 3560.

[13] Jamie Bartram and Richard Balance, UNEP/WHO, (1996). Water Quality Monitoring - A Practical Guide to the Design and Implementation of Freshwater Quality Studies and Monitoring Programmes, United Nations Environment Programme and the World Health Organization, ISBN 0419223207 (Hbk) 0419 217304 (Pbk)

[14] Khan A. A., Paterson R., Khan H., (2003). Modification and application of the CCME WQI for the communication of drinking water quality data in Newfoundland and Labrador. Presented at Proceedings of the 38th, Central Symposium on Water Quality Research, Canadian Association on Water Quality 10-11 February 2003, Burlington, Canada.

[15] Krainov S. R. and Shvets V. M., (1992). Gidrogeokhimiya (Hydro-geochemistry), Moscow, Nedra.

[16]Laluraj C. M., Gopinath G. and Dineshkumar P. K., (2005). Groundwater Chemistry of Shallow Aquifers in the Coastal Zones of Cochin. Industrial Applied Ecology and Environmental Research, 3 (1), pg. 133-139.

[17] Laptev F. F., (1955). Analiz vody (Analysis of Water), Moscow: Gosgeoltekhizdat.

[18] Maiti S. K. (2011). Handbook of Methods in Environmental Studies, Oxford Book Company, Jaipur \& New Delhi. pg. - 213-214.

[19] Mausumi Raychaudhuri, S. Raychaudhuri, S. K. Jena, Ashwani Kumar and R. C. Srivastava, (2014). WQI to Monitor Water Quality for Irrigation and Potable Use, Directorate of Water Management, Indian Council of Agricultural Research, Bhubaneswar - 751023, Odisha, India; Research Bulletin No. 71, pg. 1 - 52.

[20] Mishra P. C. and R. K. Patel, (2001). Study of the pollution load in the drinking water of Rairangpur, a small tribal dominated town of North Orissa. Indian J. Environ. Eco-planning, 5(2): 293-298.

[21] Mohemmad R. K., Rmachar T., Umamahesh M.A., (2011). study on chemical analysis of drinking water from some communities in Nandyal rural areas of Kurnool district, Andhra pradesh, India. Int. J. Civil. Struct. Eng. 2 (1), 351. 
[22] Patil S. N., Marathe N. P., Kachate N. R., Ingle S. T., and Golekar R. B., (2015). Electrical resistivity techniques for groundwater investigation in Shirpur taluka of Dhule district, Maharashtra State, India, International Journal of Recent Trends in Science and Technology, July 2015; 15(3); 567-575.

[23] Ramakrishnaiah C. R., Sadashivaiah C. and Ranganna G., (2009). Assessment of Water Quality Index for the grounwater in tumkhur taluk, Karnataka State, India. E-Journal of Chemistry 6(2), 523-530.

[24] Ravikumar P. and Somashekar R. K., (2012). Assessment and Modelling of Groundwater Quality Data and Evaluation of their Corrosiveness and Scaling Potential Using Environmetric Methods in Bangalore South Taluk, Karnataka State, India. Water Resources, 39 (4) pg. 446-473.

[25] Sahu Paulami and Sikdar P. K., (2008). Hydrochemical framework of the aquifer in and around East Kolkata Wetlands, West Bengal, India, Environmental Geology 55:823-835 (Springer) DOI 10.1007/s00254-007-1034-x.

[26] Sawyer G. N. and McCartly D. L., (1967). Chemistry of sanitary engineers, Second Edition, McGraw Hill, New York, pp. 518.

[27] Soroush F., Mousavi S. F. and Gharechahi A., (2011). A fuzzy industrial water quality index: case study of Zayandehrud river system. IJST, Trans. Civil. Environ. Eng. 35 (No. C1), 131136.

[28] Subramani T., Elango L., and Damodarasamy S. R., (2005). Groundwater Quality and its Suitability for Drinking and Agricultural Use in Chittar River Basin, Tamil Nadu, India. Environmental Geology, 47; pg. 1099-1110.

[29] Subramani T., Elango L., and Damodarasamy S. R., (2005). Groundwater Quality and its Suitability for Drinking and Agricultural Use in
Chittar River Basin, Tamil Nadu, India. Environmental Geology, 47; pg. 1099-1110.

[30] Sujatha D. and Reddy B. R., (2003). Quality Characterization of Groundwater in the SouthEastern Part of the Ranga Reddy District, Andhra Pradesh, India, Environmental Geology, 44; pg. 579-586.

[31] Sunita Kumari, Jyoti Rani, (2014). Assessment of water Quality Index of Ground Water in Smalkhan, Haryana, International Journal of Latest Research in Science and Technology, Volume 3, Issue 6: Page No.169-172.

[32]T. E. R. I., (2014). Assessing Climate Change Vulnerability and Adaptation Strategies for Maharashtra: Maharashtra State Adaptation Action Plan on Climate Change (MSAAPC), The Energy and Resources Institute, New Delhi, pages - 302 [Project Report No. 2010GW01]

[33] Tiri A., Lahbari N., Boudoukha A., (2014). Hydrochemical characterization of surface water in the Timgad watershed, East Algeria, Desaline. Water Treatment

[34] Tirkey P., Bhattacharya T., Chakraborty S., (2016). Arsenic and other metals in the groundwater samples of Ranchi city, Jharkhand, India, Current Science 110 (1), 76-80.

[35] Tyagi Shweta, Sharma Bhavtosh, Singh Prashant, Dobhal Rajendra, (2013). Water quality assessment in terms of water quality index. Am. J. Water Resources 1 (3), 34-38. http://dx.doi.org/10.12691/ajwr-1-3-3.

[36] WHO, (2011). Hardness in Drinking-water Background document for development of Guidelines for Drinking-water Quality, World Health Organization, 20 Avenue Appia, 1211 Geneva 27, Switzerland, pp-01.

[37] Yang, Y. S., Wang, L., (2010). Catchment-scale vulnerability assessment of groundwater pollution from diffuse sources using the DRASTIC method: a case study. Hydrology. Science Journal, 55 (7), 1206. 